\title{
What Geist would this gift give us: Seeing Hegel's 'Anthropology' in contemporary personology
}

\author{
DYLAN THOMAS LOTT \\ University of Illinois, Chicago
}

The work of art therefore demands another element of its existence, the god another mode of coming forth than this, in which, out of the depths of his creative night, he descends into the opposite, into externality, into the determination of the Thing which lacks self-consciousness. The higher element is Language-an outer reality that is immediately self-conscious existence. Just as the individual self-consciousness is immediately present in language, so it is also immediately present as a universal infection; the complete separation into independent selves is at the same time the fluidity and the universally communicated unity of the many selves; language is the soul existing as soul. The god, therefore, who has language for the element of his shape is the work of art that is in its own self inspired, that possess immediately in its outer existence the pure activity which, when it existed as a Thing, was in contrast to it. In other words, self-consciousness, in the objectification of its essence, abides immediately with itself. Abiding thus with itself in its essence, it is pure thought, or the devotion whose inwardness in the hymn has at the same time an outer existence. It retains within itself the individuality of self-consciousness, and this individuality is at the same time heard as a universal individuality that is immediately present. Devotion, kindled in the manifold units of self-consciousness, is conscious of its act as the act of all alike and as simple being. Spirit, as this universal self-consciousness of all, has its pure inwardness, no less than the being-for-others and the being-for-self of the individuals, in a single unity.

Hegel, Phenomenology of Spirit, $§ 710$

O would some Power the gift to give us To see ourselves as others see us!

Burns, To a Louse 
There is as much difference found between us and ourselves, as there is between ourselves and others.

Montaigne (quoted in Hermans, 2002)

In the penultimate stanza of his poem To a Louse, ${ }^{1}$ the Scottish poet Robert Burns notices the notice others are taking of said creature crawling over the bonnet of a woman in church. In that same moment, he experiences his gaze, and his awareness is immediately "expelled... as something extraneous to it." Aware of himself now as one among many, he responds by voicing a desire to "see our selves as others see us" in the hope of being freed from the folly and airs which humanity carries into its highest, most intimate and most solemn occasions. But could any Power achieve such sight and in such a way as to make of it a benediction? What are we to make of the desire for and the attempt to think such a position from which we could be known all-at-once? What is man such that he experiences himself as so many selves, yet who fights with equal ferocity to define himself against and to achieve union with his fellows?

Such questions are not confined to the spheres of poetry, religion and philosophy, though a form of their asking may be. The rational attempt to know who and what man is animates many disciplines, and it may be generative to compare a particular formulation of these questions through Hegel and SocialCognitive Psychology. And if in the end we find we cannot ourselves offer Burns any assurance, we may yet gain a glimpse of what his hope says about us all.

Contemporary currents of personality science diverge at the question of the role language plays in the constitution of the self. ${ }^{3}$ Some theorists take a reductively evolutionary view of language, such that terms for the description of persons (often simply one word descriptors) are taken to be indicative of a natural taxonomy. ${ }^{4}$ Other approaches, grounded in a more dynamic and nuanced conception of the interaction between selves and circumstances, ${ }^{5}$ examine narrative, social and imaginative constructions in relation to the self. ${ }^{6}$

One such approach is that of the dialogical self as conceived in the work of Hubert Hermans. ${ }^{7}$ Dialogical theory argues for an approach to the individual as a "dynamic multiplicity of I-positions." For Hermans, "there is no essential difference between the positions a person takes as part of the self and the positions people take as members of a heterogeneous society." "The self is the function of an "intersubjective interchange" of voices, which mediate among the internalized dialogical positions in a manner reflective of the rhythm of domination and exchange possible within society. ${ }^{10}$ Thus, drawing on Bakhtin, Hermans contends that, as individuals, we are formed in and through language, but as embodiments of a multiplicity of social discourses. ${ }^{11}$ The unique way that these discourses are instantiated, uttered and acted upon "contributes to the 
'I'-ness" of the self. ${ }^{12}$ Although many of these voices or dialogical positions remain unelaborated, manifest only as fleeting internal ejaculations belonging to no clear 'other', in times of crisis or strain or when we turn our attention to them, a certain identifiable character emerges. ${ }^{13}$

The dialogical self is considered the last in a series of four historical notions about persons and agency. ${ }^{14}$ As such, the self as dialogical is a concomitant of globalization (the proliferation of voices are what gives it its form), ${ }^{15}$ and any possible 'I' position may be experienced as liberating or 'cacophonous' depending on the context in which it is voiced. $.{ }^{16},{ }^{17}$ Thus, among the set of the possible 'I' positions are those positions which the 'I' can take with respect to itself.

While there is much discussion in the dialogical literature exploring the foundational work of Bakhtin and William James, consideration of the work of Hegel has yet to be put forward. I would like to suggest that the parallels between dialogical theory and Hegel's conception of humanity are not merely rhetorical; they help us perceive and enter into an analysis of a merely adumbrated dimension of the dialogical self: the notion of 'aim' or end. ${ }^{18}$

For Hegel the idea of 'aim' in the Anthropology is central..$^{19}$ Anthropology is that initial phase of humanity's self-investigation wherein it parses mind in an attempt to know how "the voluntary embodiments of the mental or spiritual become mechanical through habit" 20 and involuntary actions become conscious. Such study is particularly important in relation to the human voice, since "when this becomes speech, it ceases to be an involuntary utterance of the soul." 21 Thus, "language itself is exposed to the fate of serving just as much to conceal as to reveal human thoughts." 22

I take Hegel here to be suggesting that language, which serves the voice and which the voice serves, is the first manifest struggle, in the field of soul, of the mind in its attempt to externalize, recollect and "inwardize itself." 23 Thus, the very action of parsing and categorizing the living principle of the mind is, for us, the visible germ of the dynamic (at once a stage and the logic of the movement through the stages) of mind becoming aware of itself; man and mind, in order to be actual, must bring themselves under the conscious aim of an end. ${ }^{24}$ They must loose

...the meaning of mere soul, or the 'immediacy' of mind [and] in this way gain the position of thinker and subject...in which the ego excludes from itself the sum total of its merely natural features as an object, a world external to it-but with such respect to that object that in it it is immediately reflected into itself." 25

The human soul effects such a transformation based on the experience that what is "felt or sensed" is in "contradiction with its inherently infinite nature." ${ }^{26}$ This transformative act fills 
"the initially empty space of its inwardness with a content appropriate to its universality...so that now the self or the 'I' beholds itself in its Other and is this intuiting of itself."27

The human soul is thus the shape of consciousness habituated to a meaningful aim ${ }^{28}$ and "it is through... habit that I come to realize my existence as a thinking being." ${ }^{29}$ However, at first the 'I'

...knows itself only as the empty, unfulfilled 'I', and all concrete content as something other than it. Here the activity of the 'I' consists in filling the void of its abstract subjectivity, in building objectivity into itself [and] making subjectivity objective..$^{30}$

Although Hermans points to the need we have to think a "well-developed regulatory system...for flexible movement between positions and for innovation of the self" 31 , what appears to be missing in the dialogic account, and what I see Hegel as being able to provide, is the language of that 'emptying' as the 'I' or self comes in contact with the actual- another voice- and the ethical challenge inherent in the structure of its response.

Considering the mediation of the transition between consciousness and self-consciousness, and how it makes possible or arises out of the negotiation of these possible 'I' positions, Hegel states that

"the soul, when it feels limitation of its power, reflects itself into itself and expels the corporeity from itself as something extraneous to it." 32

We can perhaps offer a dialogical interpretation of this limitation as that encounter which takes the form of an address both from and to an other in which the soul (a condition for the limitation to be experienced as such) becomes aware of itself as an 'I', "for the 'I' is the lightning which pierces through the natural soul and consumes its natural being." 33 Hermans offers an analogous interpretation in historical terms: "The notion of mediated dialogue enriches dialogical self theory because it poses an important question: to whom is the speaking person speaking?"34

Given that the other is the limit case of the subject, I am asking whether the present historical construction of the dialogical idea of self is itself a limit case: a generative description which even as it makes explicit the voices and positions in our historical present, throws us back onto the question of why certain voices and not others are heard. If the dialogical self is the historically immediate shape of the self, can such hearing then ever be a choice? For the self to contemplate itself as and through these voices invites an examination of relation and internalization as such. The dialogical self, compelling in its descriptive power, returns us to the question of a subject which is aware of the limit of any possible voice, yet which is compelled to attempt the articulation 
of itself in relation to each experience of its own voice as a multiplicity and which must define itself in relation to that experience.

Thus, the self is itself at various points in play in the form of the voices and positions working through it. With Hegel we can think this dynamic movement, the rhythm between the individual and society, in terms of "a shape of spirit". ${ }^{35}$ The self is therefore the determinate actuality of various "forms of life" 36 and a person chooses to posses (to be responsible to and for) a particular voice in relation to a particular set of personal and social circumstances and realities. ${ }^{37}$ However, as Terry Pinkard points out in his reading of Hegel's reading of Antigone:

...forms of life fall apart when the demand they place on their participants for a kind of intelligibility about themselves are no longer capable of being met... various demands are experienced as virtually unconditional but also at such odds with themselves that they become experienced as failures of intelligibility, even as failures and breakdowns within our agency itself. When the 'ordinary' ceases to be a home for us...that 'shape of spirit' is exhibiting the signs of its own decay. ${ }^{38}$

We are thus led to the possibility that dialogical voices, in being heard, are on one level a sign of decay; there is some element which cannot harmonize itself and so is explicitly heard. The self-conscious attempt to correct the score cannot but begin with an agency oriented toward an introjected purpose. In the terms of our discussion, the coming on to the scene of the dialogical self is a breakdown of a previous historical habit; erosion in the field of a now forgotten aim in which the subject had subsumed the awareness of itself as an 'I'. And yet such discord and decay is a moment in and through which the subject is revealed. In the penultimate paragraph of the Philosophy of Nature, Hegel writes:

...the universality which makes the animal, as a singular, a finite existence, reveals itself in it as the abstract power which terminates the internal process active within the animal, a process which is itself abstract. The disparity between its finitude and the universality is its original disease and the inborn germ of death, and the removal of this disparity is itself the accomplishment of this destiny. ${ }^{39}$

With the next paragraph begins the Anthropology.

Thus, in thinking through the investigation of itself, mind moves to overcome its determinateness. Habituating itself to aim or meaning is itself the attempt at a determinateness which abides, but which necessitates further action to preserve it (as when the voice becomes speech).$^{40}$ It is the paradoxical struggle to place beyond becoming a determinateness which has an identity with non-determinateness; meaning...death. Mind advances in the attempt to recover from what 'I' is; 'I' is what 'I' am dying of. In the self-conscious attempt to 
find my voice among the voices, the subject is positioned in the form of a call which cannot help but being seen, in time, as a response. Hegel again:

The living being, as singular, dies from the habit of life, in that it lives itself into its body, into its reality. Vitality makes itself, for itself, into the universal, in that the activities become universal; and it is in this universality that the vitality itself dies; for since vitality is a process, opposition is necessary to it, and now the other which it should have had to overcome is for it no longer an other. ${ }^{41}$

However, how do we relate this to the broader question of Anthropology as a discipline which is generally taken to be about man's uniqueness? In this connection, psychologist Jan Branson has argued that the question of discovering man's uniqueness is a 'non-starter' insofar as " "being human' is a response-dependent property." 42 Branson understands the task of philosophical anthropology to be the sorting of biological, cultural and historical data in such a way as to allow for a "principled" distinction between man and the rest of the universe, and to show that such an effort is necessary to our being able to find meaning and purpose in our being. ${ }^{43}$ Each stage, Branson reminds us, is fraught with methodological difficulties which have often led humanity to conclusions unique only in terms of the insidious and manipulative projects it impelled them to. ${ }^{44}$ Thus, for Branson, being a human is on par with being a responsible agent and being a responsible agent is dependent on my being treated as a responsible agent by other responsible agents. The world of persons "pulls itself out of the hat", in that it is the response dependent praxis of responding to others responsibly. All of this leads Branson to conclude that "investigating the bounds of the human being is not an enterprise of finding empirical data, but an enterprise that is itself normative all the way down." 45

Thus, the question "what is man such that he can be spoken of as a polyphonic self in a globalized society' turns on the question of how he is habituated to a way of perceiving and experiencing himself. Hegel's program of anthropological investigation shows us that the force of the proliferation of normative claims ${ }^{46}$ on the individual and the aptness of the description of the polyphonic self should give us pause. Hegel helps us see that their 'coming on to the scene' speaks to the need for an explicit aim to help the self structure the terms of its recognition. Such a choice is itself a challenge to pluralistic cannons of normativity. The global village may be a free plurality, but to be a self, 'I' must decide.

Thus, the moment of recognition becomes another determination that must be superseded ${ }^{47}$ but in such a way as to preserve the agency and reciprocity of both 'I' and other. ${ }^{48}$ In other words, the dialogical self is not simply pointing to the fact that 'I' must negotiate these positions, but humanity itself must do so, which means the individual must make explicit for itself the role and the 
place its knowledge about itself has in humanity's development; the self must now factor in how it habituates itself to the claims made in the intimation of a resolution of its particularity as a individuality, itself brought into being under the intimation of "the self-related universal [which] exits nowhere save in the 'I'." ${ }^{49}$ Thus, the aim to which my soul must be directed is one in which I am habituated to choose those conditions which will allow for the agency and reciprocity in the service of meaning and normative directedness. ${ }^{50}$

But the conception of the modern globalized individual, as its own dialogical position, has suffered to the extent that it has been explicitly set up over and against all other voices and positions in virtue of its inclusiveness. We may with Hegel observe that:

....it does not recognize the contradiction it falls into in not letting the rejection which has taken place in words, be validated as a genuine rejection while itself has the certainty of its Spirit, not in an actual deed, but in its inner being, and finds the outer existence of this inner being in the utterance of its judgment. It is thus its own self which hinders that other's return from the deed into the spiritual existence of speech and into the identity of Spirit, and...produces the disparity which still exists. ${ }^{51}$

When considering the necessity of the soul to externalize its limitation as an other, it is important to emphasize that on the social, cultural and historical level that that other need not be well-defined and may in fact be synonymous with notions of the divine or the social, historical and cultural as such. Hermans himself remarks on the importance the conception of an imaginary audience or other plays in understanding the dialogical nature of the self..$^{52}$

Which returns us to Burns' plea. The rhythm of the poem's pivotal scene mirrors the historical situation we find ourselves in, wherein Geist, in the form of the notion of a dialogical self, becomes conscious of the gaze of itself as it spontaneously projects the sense of itself as arising in and from an 'other'. ${ }^{53}$ The trials of attempting to observe and define the 'person' have culminated in the awareness of how that study shapes its very object and how the desire to "see ourselves as others see us" is a gift already present, if we are willing to understand that the desire to want to see others is itself the form of our object, the "within-book" of seeing, but as yet only its "outward side". 54

\section{ENDNOTES}

1 Robert Burns, Selected Poetry and Prose, ed. Robert D. Thornton (Boston: Houghton Mifflin Co., 1966), 76-77.

2 G.W.F. Hegel, Philosophy of Mind, trans.A.V.Miller (Oxford: Clarendon Press, 1971), $152 Z$.

3 The distinction between self, Self, person, agent, individual and subject is a complicated and unsettled affair. Sensitive to the distinctions, it is beyond the scope of this paper to address 
itself to such important matters.

4 For a critique of such approaches, see Dylan T. Lott, Very like a whale: Analytic Philosophy and the Languages of Psychology; $7^{\text {th }}$ International Conference of the Academy of Linguistics, Behavioral and Social Sciences, November 16-18, 2006 (unpublished presentation) and Daniel Cervone and Dylan Lott (2007), "Language and the Languages of Psychology", European Review, 15(4), 419-437.

5 Lee Ross and Richard E. Nisbett. The Person and the Situation: Perspectives of Social Psychology (Philadelphia: Temple University Press, 1991).

6 See J. S. Bruner, Actual minds, possible worlds. Cambridge, (MA: Harvard University Press, 1986) and K. J. Gergen, The saturated self: Dilemmas of identity in contemporary life, (London: Sage, 1991).

7 See H. J. M Hermans and E. Hermans-Jansen, Self-narratives: The construction of meaning in psychotherapy (New York: Guilford Press, 1995) and H. J. M. Hermans and H. J. Kempen, The dialogical self: Meaning as movement (San Diego: Academic Press, 1993).

8 Hermans, "The dialogical self as a society of mind", 147.

9 Hubert J.M. Hermans (2002), "The Dialogical self as a society of mind", Theory and Psychology, 12(2), 147.

10 Ibid, 148.

11 Ibid, 149.

12 Ibid, 149-150.

13 Ibid, 150.

14 See Frank Richardson, A. Rogers and J. McCarroll (1998), "Toward a Dialogical Self", The American Behavioral Scientist, 41(4), 496. The four notions are: traditional, modern, post-modern and dialogical.

15 Space does not permit bringing the critiques of Deleuze and Guattari, Charles Taylor and others in to play.

16 Hubert Hermans and Giancarlo Dimaggio (2007), "Self, Identity, and Globalization in Times of Uncertainty: A Dialogical Analysis", Review of General Psychology, 11(1), p. 34.

17 Ibid,41. Therapeutically, dialogical theories help the individual to give full and explicit voice to each of the competing voices in order to create a space beyond the din, seeking not a monological hegemony, but a "polyphony of the self." See also Hubert J.M. Hermans, (2001) "The construction of a personal position repertoire: method and practice", Culture and Psychology, 7, 323.

18 Hegel, Philosophy of Mind, 150Z; cf. §410, where habit is the manner in which the soul has possession of contents which allow it to move freely, but they are formed in service of an aim, therefore I come to realize "my existence as a thinking being"143Z. So too must man become formed in the stages of consciousness toward Absolute Knowing; our existence is the habit of Geist's utterance. This 'aiming' in action is the aim of Being which must postulate an end, its end, (union of Individual and Universal). While there is no room here to consider Aristotle in connection both with Hegel's idea of 'soul' and 'aim', an interesting consideration of the latter (in a not wholly unrelated context) is put forward by B.P. Vysheslavtsev in The Eternal in Russian Philosophy, 81, trans. Penelope V. Burt (Grand Rapids, MI: Eerdman's Publishing, 2002).

19 Hegel, Philosophy of Mind, $152 \mathrm{Z}$ and 27Z. We also see here in parallel outline the history of the conception of the person- at first an immediate object in the world, next an awareness of itself as constituted in relation to another, slowly abstracting from this relation having recognized the vanity of trying to fill itself with the determinations of the other, to positing itself. It is the burden of this paper to show that the conception of persons historically unfolds as such 
a development. For it, dialogical psychology can perceive the stage at which contemporary persons are having to negotiate their individual being in relation to the social. However, without positing a beyond of that relation, they risk the pronouncement of that condition as the limit case of the human and thus of Geist. The accuracy of their diagnosis forces them, necessarily so in the work of Geist's diremption, into an explicit pronouncement about the nature of the self. It is here, in both its aptness and limit, that we must continue the unfolding of the Notion.

20 Ibid, $150 Z$.

21 Ibid.

22 Ibid, 151Z.

23 Ibid.

24 Anthropology is not identical with the study of the "the peculiarities, passions, and foibles of other men." Hegel, Philosophy of Mind, $\$ 377$. Note that Hegel goes on to say: "Information of this kind is...meaningless, unless on the assumption that we know the universal-man as man and, that always must be, as mind." The Zusatz makes it clear that neither are we discussing "human nature."

That is, we must understand that "the entire development of mind is nothing else but the raising of itself to its truth, and the so-called psychic forces have no other meaning than to be the stages of this ascent." (ibid, 6). However, these stages pose a problem for the observer because they do not have the quality of externality which Nature possesses, as their nature is to loose themselves in becoming what is necessary for mind's development (ibid, §380).

25 Hegel, Philosophy of Mind, 151Z.

26 Ibid, $152 Z$.

27 Ibid.

28 How we rise through that possibility is the first part of the Phenomenology of Spirit.

29 He goes on: "...the form of habit...is open to anything we chance to put into it; and it is habit of living which brings on death, or, if quite abstract, is death itself: and yet habit is indispensable for the existence of all intellectual life in the individual, enabling the subject to be a concrete immediacy, an ideality of soul...to be his as this self, this soul and no other..."Hegel, Philosophy of Mind, 143.

30 Hegel, Philosophy of Mind, $27 \mathrm{Z}$.

31 Hermans, The dialogical self as a society of mind, 157. Compare: “...theories of selfregulation implicitly focus on dynamic, process-oriented aspects of the self-the "I'" (pg 314) in Hazel Markus and Elissa Wurf, "The dynamic self-concept: A social psychological perspective”, Annual Review of Psychology, 1987.

32 Hegel, Philosophy of Mind, 152Z.

33 Ibid.

34 Hermans, The dialogical self as a society of mind, 154.

35 Hegel, Phenomenology of Spirit, §760 and §798.

36 Terry Pinkard, "Inside, Outside and Forms of Life: Hegel and Wittgenstein", in Hegels Erbe, ed. Micheal Quante and Christoph Halbig (Frankfurt: Suhrkamp, 2004), 14 (online trans. retrieved from http://homepage.mac.com/titpaul/FileSharing3.html : 6/02/09)

37 G. W. F. Hegel, Elements of the Philosophy of Right, trans. H. B. Nisbet (Cambridge University Press, 2007), §57.

38 Pinkard, Inside, outside and forms of life, 14. See also Richardson, Toward a dialogical self, 501.

39 Hegel, Philosophy of Nature, $\$ 375$.

40 Hegel, Philosophy of Mind, 150Z.

41 Hegel, Philosophy of Nature, $442 Z$. 
42 Jan Branson (2008), "Educatability dissolving the problem of man's uniqueness", Journal of Anthropological Psychology, 20, p. 2.

43 Ibid, 3.

44 Ibid, 5. Reasoning through Strawson's distinction between the observer and participant points of view, Branson points out that we cannot escape the danger inherent in a 'for us' perspective, which allows for potentiality, because we cannot get past that it is we who decide the principles by which others are acceptable as persons 'to us'.

45 Ibid, 5-7.

46 A fuller treatment of this matter would have to address itself to Hegel's conception of Bildung and Sittlichkeit.

47 Hegel, Philosophy of Mind, $\$ 443$.

48 See also Robert R. Williams, Recognition: Fichte and Hegel on the Other, (SUNY, 1992), 191.

49 Ibid, $152 Z$.

50 Cf. "But when I really act, I am conscious of an 'other', of a reality which is already in existence, and of a reality I wish to produce..." G. W. F. Hegel, Phenomenology of Spirit, trans A. V. Miller (Oxford University Press, 1977).

51 Ibid, §667.

52 Hermans and Dimaggio, Self, Identity, and Globalization in Times of Uncertainty, 51.

53 See also Williams, Recognition, 253.

54 Hegel, Philosophy of Mind, §462.

\section{REFERENCES:}

Branson, Jan, 2008, "Educatability dissolving the problem of man's uniqueness”, Journal of Anthropological Psychology, 20.

Bruner, J. S., 1986, Actual minds, possible worlds. Cambridge, MA: Harvard University Press.

Burns, Robert, 1966, Selected Poetry and Prose. Robert D. Thornton (ed.) Boston: Houghton Mifflin Co.

Cervone, Daniel and Dylan Lott, 2007, "Language and the Languages of Psychology”, European Review, 15(4), 419-437.

Gergen, K. J., 1991, The saturated self: Dilemmas of identity in contemporary life. London: Sage.

Hegel, G.W.F, 1971, Philosophy of Mind, A.V. Miller (trans.). Oxford: Clarendon Press. , 1977, Phenomenology of Spirit, A. V. Miller (trans.) Oxford University Press.

,2007, Elements of the Philosophy of Right, H. B. Nisbet (trans.) Cambridge University Press.

Hermans, Hubert J.M., 2001, The construction of a personal position repertoire: method and practice, Culture and Psychology, 7, 323.

2002, The Dialogical self as a society of mind, Theory and Psychology, 12(2), 147. 
Hermans, Hubert and Dimaggio, Giancarlo, 2007, Self, Identity, and Globalization in Times of Uncertainty: A Dialogical Analysis, Review of General Psychology, 11(1), p. 34.

Hermans, H. J. M and Hermans-Jansen, E., 1995, Self-narratives: The construction of meaning in psychotherapy. New York: Guilford Press.

Hermans, H. J. M. and Kempen, H. J, 1993, The dialogical self: Meaning as movement. San Diego: Academic Press.

Lott, Dylan T., 2006, Very like a whale: analytic philosophy and the language of psychology; $7^{\text {th }}$ International Conference of the Academy of Linguistics, Behavioral and Social Sciences, November 16-18, 2006 (unpublished presentation)

Markus, Hazel and Wurf, Elissa, 1987, The dynamic self-concept: A social psychological perspective, Annual Review of Psychology.

Pinkard, Terry, 2004, "Inside, Outside and Forms of Life: Hegel and Wittgenstein”, in Micheal Quante and Christoph Halbig (eds.) Hegels Erbe, Frankfurt: Suhrkamp. (online trans. retrieved from http://homepage.mac. com/titpaul/FileSharing3.html : 6/02/09)

Richardson, Frank, Rogers, A. and McCarroll, J., 1998, Toward a Dialogical Self, The American Behavioral Scientist, 41(4), 496.

Ross, Lee and Nisbett, Richard E, 1991, The Person and the Situation: Perspectives of Social Psychology (Philadelphia: Temple University Press, 1991).

Vysheslavtsev, B.P., 2002, The Eternal in Russian Philosophy, trans. Penelope V. Burt (trans.). Grand Rapids, MI: Eerdman's Publishing.

Williams, Robert R., 1992, Recognition: Fichte and Hegel on the Other. SUNY. 